\title{
QUESTIONS OF AUTHORITY, STATUS AND POWER
}

\author{
Norma Corry \\ Wits University
}

\section{Abstract}

The paper seeks to unravel some of the notions of authority and status that can be found in the context of the early Christian community. It focuses on the Christian community in first-century Corinth and, more particularly, on the occasions that they gathered together to eat a common meal, as recorded in Paul's first letter to the Corinthians. The common meal was the primary social activity of the GraecoRoman world in the first century CE, and the Christian community was influenced by its practice and social significance, as were any urban group at that time. Authority structures in Graeco-Roman society were directly dependent on the rules governing status, rules that were biased in favour of those in the upper sectors, those who by birth or inheritance, could lay claim to status and therefore authority and power. Gender roles were fixed and status for the lower sectors and for women was limited. Persons of status controlled resources through a social networking system, and this meant that a large proportion of society were obligated to them for their basic needs. Paul addresses the way in which the networking system of patronage has affected the community life of the Christians in Corinth when they met together for a meal, and holds up by contrast the values and ideals as represented by the Christian meal. The traditional interpretation of the conflict within the Christian meal sees the conflict as based on a distinction of wealth between members, but the picture is much broader. Analysing the situation using the Graeco-Roman notions of authority and status as a tool reveals a much deeper problem, and provides a way of reading texts from a different perspective. This has value, not only for contemporary women, but also for all that revisit the early Christian community records.

\section{Introduction}

Questions such as those underlying the title of this paper are obviously concerned with the social interactions of people. We cannot talk about authority and status without reference to the people who have both authority and status. Nor can we address questions of power unless we are aware that it is persons who wield it. Clearly, examples of such social questions can be found in descriptions of contemporary societies, but they may also be found in applied to ancient communities, such as the early Christian community. We will take the latter line of inquiry, focusing upon the Christian community in first-century Corinth and more specifically, the Christian community in the common meal situation. Our purpose is to show that Christians were influenced by social norms of meal practice, especially in terms of authority-status patterns, and that Paul has to challenge these patterns for the sake of the continuation of the community.

We have another purpose in mind, too. Interpretations of biblical texts have too often centered only on theological issues that have sometimes hardly ever dealt with the status of women, especially women who have wanted to engage in Christian ministry. Indeed, such interpretations have often worked to the detriment of women and their involvement in ministry. By considering the place of women in Graeco-Roman society and in the common 
meal occasions, and by examining the possible place of women in the Corinthian community's meal, we hope to engender a different reading of that text amongst both men and women readers of today. It is hoped that it will be a reading that is sympathetic to women and their role in Christian society. So too we hope to encourage Christians, both men and women, to consider the impact of modern authority-status patterns for their work in the world, and to ascertain to what degree these patterns are contrary to the vision and mission of the gospel.

Accordingly, we must therefore begin with a consideration of the prevailing conceptions of status, authority and power in the Graeco-Roman world. The community we are investigating is, after all, a community in the context of the Graeco-Roman world of the first century CE. Our first consideration is therefore to look into that world and especially to examine the social stratification and notions of status within urban Graeco-Roman life.

\section{Authority, status and power in Graeco-Roman society}

Notions of authority and status in the Graeco-Roman world are derived from the way in which Graeco-Roman society was organised. When the Romans conquered the world of the Mediterranean their chief interest was to establish and maintain effective systems of order and taxation. The Roman army naturally played an important role in achieving these aims, but the social organisation of the cities within the empire also contributed significantly to the way in which Roman control in the empire was assured. Much may be said about Graeco-Roman society, but for our purpose it is important to note that it was sharply divided along social lines, with very little mobility between positions and roles in society. It is also important to understand the way in which networks of patron-client relations controlled social interaction.

\subsection{Social division: fixed places, minimal mobility}

The sharp division between the two sectors of society, the humiliores ${ }^{1}$ the lower classes, and the honestiores, the upper classes, was maintained by legal barriers (see Verner 1983:47, also Stambaugh and Balch 1986:114). Positions in society were more or less fixed. There was little movement between the predominant group in the lower classes, that is, the slaves ${ }^{2}$, and the aristocratic classes. Those who made up the upper class belonged to established orders, topped by the senators ${ }^{3}$ and moving downwards to the equestrians and decurions, the latter being the local aristocracy. The upper classes, which represented the minority, especially were diligent about protecting their status and power. Even freedpersons, who had established themselves as wealthy people, found it difficult to move out of their particular position and role ${ }^{4}$. For most people at that time access to wealth was not

1. These terms were used in a legal sense as a description of social levels and can be substantiated by sources dating at least to the middle of the second century CE (see further Alfoldy 1985:106).

2. According to Gager, slavery was endemic then and from the first century BCE and to the first CE 'reached its highest proportion' (1971:109). It is well known that slaves had no legal rights, and were regarded as the property of their owners, who had minimal legal restrictions imposed on them. Slaves and their children were subject to lifelong obligation to their owners even after manumission (vide Verner 1983:62).

3. By the first century CE senators had begun to decline as an order and this in turn had an effect on the levels below them. The decline of this order opened the way for equestrians to be chosen as senators but movement between orders was minimal.

4. There are instances where movement between orders occurred. The Freedman Pallas, financial secretary to Claudius, was honoured by the senate in ways above his status and more in keeping with the upper classes. It was apparently quite common for senators to delegate the administrative duties to their subordinates mainly because they did not have the skills themselves (vide Meeks 1983:22, Gager 1971:101). 
easy, a direct consequence of living in what has been termed a society of limited goods (Malina and Neyrey 1991:229). There was a limit on the availability and quantity of necessary merchandise, both material and non-material. So that the ownership of property, land and desired goods, including status, was in the hands of the few, i.e., of the upper classes. The rest of the population was either in competition for a little of the resources, or enslaved or obligated to those who had control over them. Mobility was minimal and fell under the control of the prevailing social networking system of patron-client relations.

\subsection{Patrons, clients and households}

The system of patron-client relations was especially evident in social institutions such as that of the household and the voluntary associations. Historically the household was the institution through which the economy of the empire's cities was controlled. Government in the general sense of the word was first learned through the household ${ }^{5}$. Garnsey and Saller aptly sum up the role of the household:

[T] he family was the basic social unit through which wealth and status were transmitted. As such, the perpetuation of the aristocracy, the possibilities for social mobility, the distribution of landed wealth, and other matters depended fundamentally on patterns of family behaviour (1987:126).

The household was replicated many times over in the Graeco-Roman world starting with the Emperor's household, which could be considered as the prime institution in the empire. It was an important religious unit. It provided the primary needs of its members and served as a major resource for communities tied into it. Voluntary associations, for instance, relied chiefly on the household structure for their existence. Were it not for the household the associations would not meet the needs of their members, e.g., opportunities to experience positions of authority and governance within the association ${ }^{6}$.

The paterfamilias or the head of such a household would be responsible for supporting the entire household and would therefore require considerable means to do so. Research done on housing in the Graeco-Roman first century world has shown that the majority of peoples probably lived in one and two roomed apartments or insulae and that very few people lived in private mansions of the type that could accommodate an extended household (see further Verner 1983:54-63) ${ }^{7}$. It may be that the house in which the Christians met to eat their meal may have been of the mansion type, i.e., large enough to accommodate the church in Corinth. To own a house and more importantly, to be head of a household would be a claim to wealth and some status, but would not necessarily be an indication of status in the wider community, unless the paterfamilias was a member of the upper orders. Status and power were a means to wealth, but wealth was not necessarily a means to status and power. This 'status inconsistency', a term coined by Meeks, could well apply to members of

5. This idea that politics emanated from the household can be found in the thinking of Aristotle (Pol vol 1). In Philo we read of a correlation between household management, oikonomia, and state management, politeia (Ebr 92, SpecLeg 3.170).

6. The internal organisation of associations mirrored that in the wider society (see Banks 1980:16, Meeks 1983:24-31). It is well known that voluntary associations attracted those who were not able to participate meaningfully in the household or the state institutions.

7. This research on housing supports the picture that has emerged of the social stratification of cities in the first century, viz, that few people belonged to the upper classes and most people could be found amongst the lower classes, that is the slaves and freed-persons. 
the Corinthian community among whose members were several who owned houses (1983:70).

Authority lines can be observed in the household structures, within which women and men had particular roles. The paterfamilias expected obedience from the members of the household, that is, nuclear family, extended family, slaves, freed-persons and clients. $\mathrm{He}$ acted as father and husband but also as priest and patron to the household. The household was traditionally the place for women, and the traditional role of women was one of serving. By contrast the traditional role for men was one of ruling. Corley notes that there was a dichotomy between the 'public' and 'private' spheres of society in terms of gender roles (1993:15, see also Fiorenza 1983:176). The private sphere was in effect the household to which women were confined. The public sphere of the forums, law-courts, theatres, lectures and public banquets was open to men but closed to women - women who were regarded as respectable, that is. Respectable women who ventured into the public sphere had to be accompanied and had to be veiled. The only women who had cause to be in the public sphere were those of the lower classes, generally slaves and freed-persons who went about the business of their owners or employers. Any woman who entered the public domain was in danger of being termed a prostitute ${ }^{8}$ (see Corley 1993:15-17).

Roman law at that time required women to be under permanent male guardianship. Although there is slight evidence that the social view of women was changing at that time, it is likely, however, that any new freedoms accorded women were subjected to male scrutiny and permitted only if there were unlikely to be political implications (Corley 1993:54). This included the owning and selling of property. The one area where women could exercise more authority was in the religious cults - they could take on the role of priestess, but usually only in the cults honouring a female deity.

Although there were laws restricting inheritance for women, there is evidence that Roman women in the first century owned property and wealth which they used in public benefactions, or to hold public office and generally function as patrons (see Garnsey and Saller 1987:130, Verner 1983:39, Corley 1993:11-12). This is an important point for our purposes because of the probability that the Christian community in Corinth included women patrons as members. As we have already indicated, patronage was a significant phenomenon in Graeco-Roman society.

The primary feature of the patron-client system was reciprocity, so that what was offered whether it was protection, financial loans, food or job opportunities always had an expectation of some sort of return attached to it. This 'return' usually took on the form of expressions of honour and loyalty (Moxnes 1991:242). The focus was on giving and receiving only amongst those with something to offer in exchange? Those who had something to offer were termed 'friends'. At that time a friend would be one with whom one entered into a social contract (See Garnsey and Saller 1987:11, also Marshall 1987:124). A patron would gather as many friends around him as possible with the purpose of making clients by giving to them what they needed and receiving from them gestures of honour in

8. As Corley has noted, the term 'prostitute' was a term used against women of all social levels, not just freewomen or slaves or prostitutes. It seems to have been directed at women who freely associated with men in the public sphere, and inappropriately at meal occasions (1993:63).

9. There was little room for charity, as Stambaugh and Balch (1986:64) point out: 'Charity for the poor and destitute, who could not offer anything in exchange, was virtually unknown. Even when we do hear of donations of food or money, the largest portions always go to the more prosperous members of the recipient population, those who can make the most impressive return. If the most needy do receive something, it seems to be coincidental to the main purpose of the donation.' 
return. In fact the system of patronage cannot be discussed without reference to the value system of honour and shame, that Malina regards as 'pivotal' values in the first century world (1981:25-27, see also Moxnes 1988:207-8).

Honour in the Graeco-Roman world revolves around the status of an individual in the eyes of a relevant social group (Esler 1994:25, Moxnes 1988:208 ${ }^{10}$ There were two paths to honour. It could be ascribed through either birth or inheritance or it could be acquired through the system of benefaction as described above. All social contracts were seen as opportunities for honour concessions, or for honour contests. Moxnes sums up the main characteristics of this value system as follows:

In the Graeco-Roman world the group was more important than the individual. The individual received status from the group. Therefore, recognition and approval from others were important. interaction between people was characterised by the competition for recognition and the defense of one's own status and honour. To refuse a person's claim for honour was to put the person to shame. The basic notion of all studies of honour and shame is that they represent the value of a person in her or his own eyes but also in the eyes of his or her society (1988:208).

In daily social interactions the patrons were expected to provide the necessary resources for their clients. They, in turn, would reciprocate with gestures of honour, such as setting up an inscription, arranging a procession or giving them the best place at a banquet. Although patrons were comprised primarily of the upper levels of society, evidence indicates that equestrians could take on the role of patron. Erastus of Corinth (Romans 16:23) could be just such a person, although there is some debate as to the exact nature of his position (see Malherbe 1983:72, Meeks 1983:58 $)^{11}$.

Patron-client relations with its value system of honour and shame invaded the whole of urban life including the Graeco-Roman common meal, and Stambaugh and Balch sum up the prevailing attitude well in their remarks on status with specific reference to meals:

Legal barriers emphasized the gulf between the orders. These were informal but real.

Members of the senatorial aristocracy were forbidden to marry former slaves, separate courts tried the upper classes and the lower classes, and separate punishments were decreed...Even at meals, whether private dinner parties to which a rich patron invited some of his clients or public banquets given by an aristocrat for his fellow citizens, your place and even what you got to eat depended strictly on your status; the invitation to 'come up higher' would never be extended to one of inappropriate status, although some Roman authors thought that everyone at a dinner should eat the same food and be accessible to each other (1986:114).

The above quotation allows us to discern that the meal played a significant role in establishing status boundaries and authority roles.

10. The personality type of the first century, described as a dyadic personality was rooted in community so that people did not only perceive themselves as individuals but as members of the community. This meant that they were dependent on the ascriptions of significant others in their community to validate their significance or self worth (Malina and Neyrey 1991:32, Esler 1994:29).

11. It is likely that freed-persons who had accumulated wealth and had administrative ability were given positions of public responsibility that allowed them to function as patrons. 


\subsection{The Graeco-Roman common meal}

The so-called common meal, an evening meal, was the primary social event of GraecoRoman society. Such was the frequency with which these meals occurred that all levels of society, including slaves, would have had occasion to participate in them (see Willis 1985:15). There is strong evidence that these meals formed a significant part of the festivities of most, if not all of the associations. Independent research undertaken by both Smith (1980) and Corley (1993), has shown that a particular meal format was common to all groups. In other words those meeting in voluntary associations or as Jewish groups or as households or as Christian groups all followed the same basic pattern of meals. The pattern can be described as follows. There were two parts to the meal, the deipnon and the symposium. Bread was served at the commencement of the deipnon and a meal followed. The main drinking part was left to the symposium at the end of the supper when all the dishes were cleared away. A cup of wine was passed around to mark the commencement of the symposium. Philosophical discussion or some sort of entertainment would generally take place during this latter part of the meal.

Everyone had a proscribed place at the meal, the highest place being reserved for the guest who carried the most status. Respectable women were generally prohibited from dining with their husbands at public functions, with the exceptions of weddings and funerals. When they were allowed at table they generally had to sit at the feet of their husbands, or they were grouped with other women on separate couches ${ }^{12}$ (see Smith 1980:210, Corley 1993:26-30). For the most part women ate in separate quarters. The only women allowed into meals on a regular basis were the flute girl and other entertainers. Women who sponsored associations as patrons ${ }^{13}$ would be included in association banquets, but would have to maintain a standard of morality (see Corley 1993:33-34).

\subsection{The social significance of meals}

Common meals had special significance in the social interactions of a city. They acted as a means of confirming roles in society and relationships amongst participants. They served as indicators of friendship and more significantly as indicators of status. Both the quality of food served and the place at table assigned to guests would indicate the status of an individual, and the more lavish the food the greater the indication of his importance in the society. Superior food was offered to officials of voluntary associations in their meals, and to social equals in the meals of the elite. Literature of the time indicates that it was a usual occurrence for hosts to serve different quality meals to guests at the same meal ${ }^{14}$. Several sources indicate that a refusal to eat what was served or an unwillingness to participate in a meal was regarded as abnormal and in the words of Gooch 'requiring justification' (1993:43). Apparently meal invitations were refused if it was felt that, by attending, the status credibility of the invitee would be at risk. Social progress therefore corresponded with the degree to which a person conformed to social norms, such as those found in common meal practice. Gooch sums the situation up correctly when he says:

In Graeco-Roman society, you were what you ate, and - more important - you were whom you ate with (1993:38).

12. Allowing women at some meal occasions was a particular Roman innovation that the Greeks may not necessarily have embraced (see Smith 1980:210).

13. Evidence suggests that male patrons outnumbered female ones by about 14 to 1 (Corley 1993:34).

14. For instance, Plutarch (Plu Qconv 697C) and Pliny (EP 2.6). The philosophical ideal was equality around a meal table, but in practice this was probably not realised (for a discussion on symposium traditions see Corry 1997:37-40). 
The fact that Graeco-Roman meal ideology associated the presence of women at meals with the lower classes and with prostitution, nevertheless hindered women from participating in these occasions (see Corley 1993:78).

\subsection{Summary}

In completing this section regarding the context of the Christian community in Corinth, we see several significant facts emerging concerning the prevailing status-norms that indicate the base of authority and power. To begin with, only those with designated birth and inheritance credentials had any real status in society. This meant that those who were from Roman or local aristocratic families were regarded as the top of the status ladder. Laws governed social movement up the ladder, ensuring the continued status of the upper classes. This in effect gave them authority and kept them in power, and in control of resources such as land and education. A measure of status was accorded to freed-persons who had accumulated wealth and who functioned as patrons, but it was status amongst their own group and certainly not within the upper levels of society.

Furthermore, Graeco-Roman society was a male dominated society. Governing positions were given to men who controlled the public sectors, while women's place was in the household: But even there the men ruled - the paterfamilias had supreme control over his wife and children.

What is also significant is the fact that an individual could not enter into social dialogue unless he had some reciprocal value. For those without houses this meant forming obligation ties with patrons, i.e., with those who had the necessary resources. For some people, life depended on what they could offer in exchange for a meal. All that many others had to offer was themselves - their presence in a procession honouring a patron, or their bodies in a life of slavery accompanied often by prostitution. The underlying ethos was one of dependence.

\section{A social profile of the Christian community in Corinth}

Concerning the social levels of the Pauline communities, there is near consensus that the communities in general consisted of people of varying status and wealth (see Malherbe 1977:29-59, Meeks 1983:55-73). A profile of the Christian community in Corinth would reveal Jew and Greek, freed-persons and slaves, men and women of independent means, and probably some from Caesar's household, who would have been in Corinth as part of the 'civil service'. The Pauline correspondence names a total of seventeen people in relation to the Corinthian community, and it is Theissen's view that at least nine 'belong to the upper classes' $(1982: 95)^{15}$. He bases his argument on Paul's statement about those who were 'noble', or 'wise' or 'powerful' (1 Corinthian 1:26). His claim is considered as an exaggerated one, and it is more likely that the Corinthian community was not fully representative of Corinthian society, as Meeks has suggested. There is little evidence, claims Meeks, to indicate that the 'extreme top and bottom of the Graeco-Roman scale' are included in a list of members (Meeks 1983:73). Peasants and jobless poor would probably not be members of the community, as neither would senators.

Many persons are recorded as owning houses ${ }^{16}$, and this would give them a measure of status within their immediate community. Gaius is recorded as having the Christians meet at

15. He names them as Crispus, Erastus, Prisca, Aquila, Stephanus, Gaius, Phoebe, Justus, Titius and Sosthenes.

16. Gaius (1 Corinthians 1:14), Crispus (1 Corinthians 1:14, Acts 18:8), Stephanus (1 Corinthians 1:16)< Titius Justus (Acts 18:7), Priscilla and Aquila (1 Corinthians 16:19, Romans 16:3-5). 
his house. Women mentioned include Prisca, (who was probably of higher status than her husband Aquila, see Meeks 1983:59), and Phoebe the latter being described as patron ${ }^{17}$ (Romans 16:1-2). Many regard Erastus as a freedman holding an important office in the wider community (see Meeks 1983:58-59). Many have Latin names, which could be an indication of status. Overall, several examples of persons with some measure of status can be cited: those running households, holding office, having Latin names etc.

The Christian community met in houses around a common focus, Jesus Christ. As such they shared common features with voluntary associations, the most common being the practice of the common meal. Several persons ${ }^{18}$ could have hosted the Christian meal. By providing a meeting place they fulfilled the role of patron, that would also include the provision of food for the meal. Their whole household, both kin and fictive kin, would probably have been included in the meal (cf. Acts 16:32). Despite the fact that there is little evidence within the Pauline correspondence of persons being in formal office within the community, it is likely that someone directed the proceedings at the meal. Paul singles out certain people in the community, such as Stephanus, who is called a fellow worker (1 Corinthians 16:15), and also Prisca and Aquila who acted as patrons to Paul and the Christian groups wherever they settled, as did Phoebe. It is possible that Meeks is right when he suggests that

.... position of authority grows out of the benefits that persons of relatively higher wealth and status could confer on the community (1983:14).

Someone in the Corinthian Christian community would have supervised the meal, and it is likely to have been someone who owned a house. This fact will become clearer as we examine the conflict situation in the Christian meal as reported in the Corinthian correspondence (1 Corinthians 11).

\section{Conflict in the Christian meal}

The issue that Paul addresses in his letter to the Corinthians has to do with disparity in the provision of the meal and in the eating of the meal (1 Corinthians 11:20-21). When the Christians came together to eat the meal, there were both excesses and deprivations amongst the participants as well as a lack of understanding about the purpose of the meal. Some went without food, others had too much and some got drunk.

The traditional explanation for the situation attributes the conflict to differences between rich and poor, on the basis of class distinction (Barrett 1968:262-64, Bornkamm 1969:126). The rich, 'the haves' provided the food and the poor, 'the have-nots' went without. However, scholars use the word class in a more contemporary sense and discuss the conflict in terms of a difference in wealth only. The situation is more complex than a division between rich and poor. Paul does not use the word poor (ptochos) in his discussion, and this suggests that he means more than economic deprivation - the notions of status and power should also be considered.

The following construction emerges when reading the text from a perspective of the prevailing social norms, as Theissen, Meeks and others have done. Those with houses provided food for the meal and because they were patrons it was quite permissible for them

17. Paul uses the word prostatis with reference to Phoebe. The customary translation of this word is 'helper', 'servant' or 'patroness', but there is no reason to accept the translation that concurs with the Latin patrona (see Meeks 1983:61, Fiorenza 1983:181).

18. For instance, Paul refers to Gaius as host (xenos) to the church at Corinth, which probably was a reference to the entire Christian community in Corinth (Romans 16:23, cf 1 Corinthians 16:19, Romans 16:5). 
to differentiate along status lines between the quality of food given to guests precisely because they were patrons. The discrepancies in the meal that resulted in some members eating their own meal can be explained by the fact that in common meal practice food was often distributed on the basis of status.

It is not impossible to conceive of the situation in the Corinthian community meal as similar to the normal Graeco-Roman meal practice. One or more persons assuming the role of patron would supply food for the whole gathering and would differentiate between members by giving the better quality food to their social equals, and giving inferior quality food to the rest of the gathering. It is possible that they provided food only for a particular status level alone and ignored any level below them. As Theissen points out the practice of food differentiation would not have been thought unusual in a city like Corinth because the custom was widespread (1982:156). The Christians were in fact behaving according to the social norms, or, in the words of Theissen, according to 'class-specific expectations' (1982:162). By their actions the patrons would be ascribing honour to those to whom it was due, thereby confirming status and maintaining distance between patron and client.

\subsection{Paul's challenge to the Christian community}

Paul challenges the Christians in terms of the authority-status patterns that are evident in the meal. He directs his challenge at the patrons, 'the haves', that is, the ones who own houses, by posing the question me gar oikos ouk echete eis to esthiein kai pinein; (1 Corinthians 11:22, do you not have houses in which to eat and drink?). We can interpret his question as a reference to the social dining customs of those who have status. Paul appears to be saying that this group should not confuse customary common meal practice with the Christian meal. They should not bring their traditional customs into the kyriakon deipnon, the Lord's meal. They should not differentiate in the food offered on the basis of reciprocity, as this means that those who are lower on the social scale, those that cannot contribute, would go without.

Paul further challenges the status group with the question kataphroneite kai kataischynete tous me echontas (1 Corinthians 11:22). With Paul's social background in mind, the word kataischynete can be interpreted very well in terms of the values of honour and shame. Those with status, accustomed as they were to dining with social equals, were doing so with the intention of bestowing honour in the manner of reciprocity. Paul is focusing on the fact that by bestowing honour on their social equals, the patrons have brought shame to the Christian members who cannot participate in the system. They have regarded those with lower status as having no worth in the eyes of the Christian community.

Paul's directives to the status group center on the preservation of the Christian meal as one that aligns with the traditions of Jesus. He instructs them to satisfy their hunger at home before coming to the meal. Not only that, but he also instructs them to wait for each other (allelous ekdechesthe), i.e., to wait for those without status too. This could mean that they are to wait and eat together, but could also mean to welcome each other (see Witherington 1995:252). They can behave according to social norms in other meals, but in the Lord's Supper they are, as Theissen puts it, to consider the 'norms of the congregation' as having 'absolute priority' over those of their broader communities (1982:164).

In terms of the social norms, the directive to eat together or to welcome each other, is a radical one. Should the status group act on Paul's challenge, it would entail serious consequences for them. Meals were opportunities to display status and bestow honour, and also foster patron-client ties. To surrender social status and opportunities to extend their patronage base could impinge on the livelihood of those with status. It was important to 
maintain social status, for the sake of survival. To be seen to be mixing with those of inferior status in an inappropriate manner would thus have serious consequences.

Paul's challenge to the community's authority-status patterns would also have consequences for the women members of the community. Paul's references to women in the Christian community of Corinth were always favourable. He calls Prisca, and her husband, fellow workers (Romans 16:3). Paul commends Phoebe as someone who has helped him and other fellow Christians (Romans 16:1-2). As we have already noted, Phoebe is also referred to as patron, and we can assume that Prisca has acted as patron too since she and her husband probably opened their house to the Christian community wherever they settled (cf. 1 Corinthians 16:19). Although the incidence of women becoming patrons was increasing at that time, it is not certain that they participated as social equals in common meals. The fact that meal ideology associated the presence of women at common meals with women of inferior status and morals, would suggest that it was not common practice.

There is, nevertheless, good reason to believe that women were present at the Christian meals. Both Paul's egalitarian statements elsewhere (Galatians 3:28), and his metaphors of the Christian community, e.g., 'body' (1 Corinthians 12) ${ }^{19}$, as well as his general silence in the Corinthian correspondence about women at the meal, could lead us to conclude that for Paul it was probably an accepted practice ${ }^{20}$. If this were to be the case, it would not go unchallenged. It may have been the practice for women to be seated on the floor in an inferior position. Although this is not specifically addressed in the texts, such a position would not fit in with Paul's egalitarian theology - no one should be shamed, but rather everyone should be honoured because of their position in Christ. The challenge for the community would be to break with normal tradition and include women alongside men. This would have its own repercussions in the light of the prevailing norms and it is possible that the status group would have resisted such a move.

Paul had a different understanding of the purpose of the Christian meal than that prevailing in the Corinthian community. In Paul's understanding the purpose of the Christian meal, or Lord's meal, was not only to commemorate the death of Jesus but also to celebrate his resurrection and anticipate his return (1 Corinthian 11:23-26). The focus of the meal was to be on the remembrance of Jesus. It was a meal in the tradition of Jesus, that is, a meal tradition that was handed down from the meal that Jesus had with his disciples before his death. Jesus used the bread in self-representation. Paul links the cup with the covenant - that covenant instituted by the death of Jesus (1 Corinthians 11:25) ${ }^{21}$. The meal was in remembrance (anamnesin) of Jesus, a phrase peculiar to the Pauline institution saying, and not found in the synoptics. In Hebrew thought, to remember someone meant to renew one's relationship with that person. In this case, it would entail renewing the new

19. In this passage Paul's emphasis is on the egalitarian nature of the Christian community's times of gathering together for worship. Each person is exhorted to contribute something to the meeting, whether it be a hymn, a tongue, a prophecy, a word of encouragement etc. The analogy that Paul uses of the body is meant to show that every member is significant and indispensable to the group. The text does not suggest that there is a hierarchical system at work in the Christian community. Rather there is a suggestion of equality amongst the members.

20. Evidence from the late second century indicates that the presence of women in gatherings was a question under discussion because of the entrenched ideology about women at meals. Clement of Alexandria cautions Christian women about attending public banquets (see Corley 1993:77-8).

21. Paul focuses on one part of the meal, the elements of bread and wine, but this does not necessarily mean that these elements were a separate part of the meal. Theissen is likely to be correct when he states that there is a meal between the breaking and sharing of the bread and the drinking of the cup (1982:152, see also Smith 1981:325). 
covenant relationship with Jesus (see Ashby 1988:104, Keck 1998: 61). Renewing this relationship resulted in the community deriving certain benefits, i.e., the benefits ${ }^{22}$ of belonging to one family and one community ${ }^{23}$, in which they were brothers and sisters (cf. Galatians 3:28).

From what Paul says, it is evident that new authority-status patterns emerge as relevant in relation to the community. Each member of the community is to be regarded as a person of worth and status, based on the fact that all are in Christ from whom their status is derived. The symposium part of the meal should include participation from every member - each person can contribute to the gathering (1 Corinthians 12). There is no suggestion that women should depart or that slaves should withdraw. No single person is dominant, rather each member has authority, invested through the Spirit, and all are joined to the head, Jesus. Authority should therefore be seen as operating functionally for the benefit of all members, and not hierarchically for the benefit of the few. Relationships are to be characterised by love (agape 1 Corinthians 13). It is in the meal that the egalitarian nature of the Christian community could best be seen, where social differences are put aside in favour of equal sharing. By gathering together as equals at meals, the Christians could share in what the Spirit promotes - agape, common attitudes, common goals, and a common freedom. They would demonstrate a freedom to opt out of the patron-client system that threatened to wreck relationships in the community. Giving would entail no expectation of making clients in return.

\section{Conclusion}

We have seen that members of the Christian community in Corinth came from differing social levels and were controlled by a system that separated them in to two basic 'societies': those who had and those who did not have, in terms of status and access to resources. If a person was not a patron then s/he was a client or a potential client. Members of the status group among the Christians were influenced by the prevailing authority-status patterns to the detriment of their Christian community. Paul challenges them to reject these patterns in favour of new ones that are based on a new system, one in which love and not reciprocity is the operating factor. If the community followed Paul's directives it could be quite costly for them in terms of status and credibility loss. He is asking much of them, but he feels that the existence of the community is at risk.

The above exposition challenges women to take their rightful place amongst the Christians and reject any subservient place accorded them by the wider society. For, the Christian women who acted as patrons because they owned houses, probably enjoyed a status within the Christian community that they would not normally have had in Corinthian society. They would have power amongst the members and would probably have developed authority-status patterns in accordance with the general norms. They would be challenged to forego their acquired status and embrace the new authority-status patterns presented by Paul. Adhering to the new authority-status patterns, derived not from their role as patron but from their covenant relationship with the head of the Christian community, Jesus Christ,

22. The participants share in the benefits of what was accomplished by Jesus in his sacrifice (see Marshall 1980:120, Ashby 1988: 104, Witherington 1995:224-26).

23. By the community being inclusive in this way they would be following in the tradition of Jesus - the gospels record several situations in which Jesus joined together with people of differing status - sometimes even the outcasts - in a meal. 
would entail inclusion of the most lowly slave as an equal member. Authority is given to all on the basis of equal partnership amongst members, irrespective of gender, race or class

This would not have been an easy position for the women who had some material means to adopt at that time. Firstly, it would mean giving up a position of power that they probably had acquired in the Christian community. In providing resources for the Christian community and acting as patrons would have given them some authority over others in the community. The fact that Paul spoke so well of women such as Phoebe and Prisca would have endorsed their position in the eyes of the Christian community. Secondly, their role as patron would have placed pressure and responsibility on them to maintain their place in the networking system. This may have been so, not only for reasons of status, but also for reasons of survival. So they probably found themselves, as both Christian women and patrons, in the precarious position of compromising their faith.

For today's women, the challenge is many-fold. There is the challenge to re-read the texts about the Corinthian community with new eyes. This means examining the text in the light of socio-historical research to determine what the situation meant to both the men and women of the time. It may not be such a generalisation to say that texts are interpreted with men in mind. Women are called to revisit the roots of Christian community and, for instance, to look closely at what the gospel message says in the context of the Christian meal. The meal is one that demonstrates allegiance to Jesus, and to Jesus only. Paul rejected the authority-status patterns that dominated the meal practice of the Christians, because their allegiance was to the prevailing norms and not to Jesus who was the focus of the meal.

So women are challenged to take their place in the Christian context as people who have status because they are in a covenant relationship with Jesus. Women are challenged to read texts with the eyes of those who have authority and status, and to assume a position of freedom in ministry. They are challenged to see that their authority is based on that position of status as members of the Christian community. This is a break away from the traditional view that prevails in some church groups, i.e., that authority is vested only in the clergy, or in male clergy.

Both men and women are challenged to revisit the first century Christian community and capture some of the original essence, and to use that as a yardstick with which to measure their beliefs and actions as Christians. Paul's questions and challenges to the Corinthian Christian community may apply equally well to contemporary Christian community in terms of gender, racial and social boundaries. The challenge of reading texts in context is to ascertain to what degree contemporary Christian praxis conforms to the original vision and mission of the church, or to the prevailing status quo. 


\section{BIBLIOGRAPHY}

Alfody, G 1985. The Social History of Rome, translated by D Braund and F Pollack. London and Sydney: Croom Helm

Ashby, G 1988. Sacrifice: Its Nature and Purpose. London: SCM Press.

Banks, R 1980. Paul's Idea of Community: The Early House Churches in their Historical Setting. Exeter: Paternoster.

Barton, SC 1986. Paul's Sense of Place: An Anthropological Approach to Community Formation in Corinth. NTS 32, 225-46.

Benko, S and O'Rourke, JJ (eds.) 1971. The Catacombs and the Colosseum: The Roman Empire as the Setting for Primitive Christianity. Valley Forge: Judson.

Corley, KE 1993. Private Women and Public Meals: Social Conflict in the Synoptic Tradition. Massachusetts: Hendrickson.

Corry, NA 1997. Koinonia: The Genesis of the Pauline Construct. Unpublished MA dissertation, University of the Witwatersrand, Johannesburg.

Esler, PF 1994. The First Christians in their Social Worlds. London and New York: Routledge.

Gager, JG 1971. Religion and Social Class in the Early Roman Empire, in Benko, S and O'Rourke, JJ (eds.) 1971. The Catacombs and the Colosseum: The Roman Empire as the Setting for Primitive Christianity. Valley Forge: Judson, 99-119.

Gager, JG 1975. Kingdom and Community. New Jersey: Prentice-Hall.

Garnsey, P and Saller, R 1987. The Roman Empire: Economy, Society and Culture. Berkley and Los Angeles: University of California Press.

Gooch, PD 1993. Dangerous Food: 1 Corinthians 8-10 in its Context. Studies in Christianity and Judaism 5. Ontario: Wilfrid Laurier University Press.

Judge, EA 1960. The Social Patterns of Christian Groups in the First Century. London: Tyndale.

Keck, LE 1988. Paul and his Letters. Second edition. Proclamation Commentaries. Philadelphia: Fortress Press.

Malina, B 1981. The New Testament World: Insights from Cultural Anthropology. Atlanta: John Knox.

Malina, B and Neyrey, JH 1991. First-century Personality: Dyadic, not Individualistic, in Neyrey, JH (ed.) 1991. The Social World of Luke-Acts: Models for Interpretation Massachusetts: Peabody Press, 25-65.

Marshall, P 1987. Enmity in Corinth: Social Conventions in Paul's Relations with the Corinthians. Tubingen: Mohr.

Meeks, WA 1983. The First Urban Christians: The Social World of the Apostle Paul. New Haven: Yale University Press.

Moxnes, H 1988. Honour, Shame and the Outside World in Paul's Letter to the Romans, in Neusner, J et al (eds.) 1988. The social World of Formative Christianity and Judaism: Essays in Tribute to Howard Clark Kee, Philadelphia: Fortress, 207-218.

Neusner, J et al (eds.) 1988. The social World of Formative Christianity and Judaism: Essays in Tribute to Howard Clark Kee, Philadelphia: Fortress.

Neyrey, JH (ed.) 1991. The Social World of Luke-Acts: Models for Interpretation Massachusetts: Peabody Press. 
Smith, DE 1980. Social Obligation in the Context of Communal Meals: A Sstudy of the Christian Meal in 1 Corinthians in Comparison with Graeco-Roman Common Meals. Unpublished D. Th. thesis, University, Massachusetts.

Smith, DE 1981. Meals and Morality in Paul and His World. SBL Seminar Papers 20, 31939.

Stambaugh, JE and Balch, DL 1986. The New Testament in its Social Environment. Philadelphia: Westminster.

Theissen, G 1982. The Social Setting of Pauline Christianity. Philadelphia: Fortress Press. Verner, DC 1981. The Household of God: The Social World of the Pastoral Epistles. California: Scholars Press.

Witherington, B 1995. Conflict and Community in Corinth: A Social-rhetorical Commentary on 1 and 2 Corinthians. Grand Rapids: Eerdmans. 